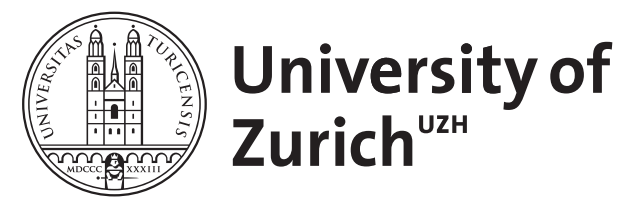

\title{
The emergence of echinococcosis in central Asia
}

\author{
Torgerson, Paul R
}

\begin{abstract}
Following the collapse of the Soviet Union in 1991, there was an increase in the number of cases of human echinococcosis recorded throughout central Asia. Between 1991 and 2001 incidence rates of cystic echinococcosis (CE) increased by 4 fold or more. There also appeared to be increases in prevalence of $\mathrm{CE}$ in livestock and prevalences of Echinococcus granulosus reported in dogs. The increase in human echinococcosis was associated with changes in livestock husbandry, decline in veterinary public health services, increases in dog populations and increased poverty, all of which served to promote transmission of E. granulosus. A few years after reports of increased transmission of E. granulosus, the first reports of E. multilocularis infection in dogs were recorded. Further studies indicated that in both Kazakhstan and Kyrgyzstan prevalences of up to $18 \%$ were present. Recently there has been a dramatic increase in the number of cases of human alveolar echinococcosis recorded in Kyrgyzstan with over 60 cases reported in 2011.
\end{abstract}

DOI: https://doi.org/10.1017/S0031182013000516

Posted at the Zurich Open Repository and Archive, University of Zurich

ZORA URL: https://doi.org/10.5167/uzh-78236

Journal Article

Accepted Version

Originally published at:

Torgerson, Paul R (2013). The emergence of echinococcosis in central Asia. Parasitology, 140(13):16671673 .

DOI: https://doi.org/10.1017/S0031182013000516 
3 P. R. TORGERSON,

4

5 Section of Epidemiology, Vetsuisse Faculty, University of Zurich, Winterthurestrasse 270, 8057 Zurich, Switzerland, tel:

6 +414463590 41; email paul.torgerson@access.uzh.ch

10 SUMMARY

11 Following the collapse of the Soviet Union in 1991, there was an increase in the numbers of cases

12 of human echinococcosis recorded throughout central Asia. Between 1991 and 2001 incidence rates

13 of cystic echinococcosis (CE) increased by 4 fold or more. There also appeared to be increases in

14 prevalence of CE in livestock and prevalences of Echinococcus granulosus reported in dogs. The

15 increase in human echinococcosis was associated with changes in livestock husbandry, decline in

16 veterinary public health services, increases in dog populations and increased poverty all of which

17 served to promote transmission of E. granulosus. A few years after reports of increased

18 transmission of E. granulosus, the first reports of E. multilocularis infection in dogs were recorded.

19 Further studies indicated that in both Kazakhstan and Kyrgyzstan prevalences of up to $18 \%$ were

20 present. Recently there has been a dramatic increase in the number of cases of human alveolar

21 echinococcosis recorded in Kyrgyzstan with over 60 cases reported in 2011.

23 Key words: Emergence, cystic echinococcosis, alveolar echinococcosis, Echinococcus granulosus,

24 Echinococcus multilocularis, epidemiology.

26 Running title: Echinococcosis in Central Asia 


\section{INTRODUCTION}

28 The collapse of the Soviet Union in 1991 was followed by severe economic hardship and was

29 associated with increases in mortality and decreases in life expectancy across the region (Becker

30 and Hemley, 1998; Becker and Urzhumova, 2005; Stillman, 2006). At the end of last decade of the

$3120^{\text {th }}$ century it became apparent that there was evidence of increased numbers of human cystic

32 echinococcosis (CE) in the former Soviet Republics of central Asia (Table 1). Official government

33 statistics in Kazakhstan document an increase in cases of CE from about 200 cases per year until

341994 , rising rapidly to approximately 1000 cases per year by the beginning of the $21^{\text {st }}$ century

35 (Torgerson et al. 2002). This epidemic emerged at a time of rapid economic decline, and decreases

36 in medical services and hence was unlikely to be an artefact caused by improved diagnosis.

37 Likewise there was strong evidence from neighbouring Kyrgyzstan that a similar phenomenon was

38 present (Torgerson et al. 2003b). In Tajikistan it was reported that the number of cases increased

39 from 374 cases in 1992 to 1875 cases in 2002 (Muminov et al. 2004). Subsequently data became

40 available that confirmed there similar epidemics were occurring in Uzbekistan and Turkmenistan

41 (Torgerson et al. 2006). Furthermore in Uzbekistan there is very strong evidence that officially

42 reported cases are a substantial underestimate of the numbers of cases being treated. A detailed case

43 finding study of all hospitals in Uzbekistan uncovered approximately four times the numbers of

44 cases of CE then were being reported in Government statistics (Nazirov et al. 2002). Unpublished

45 figures suggest that the numbers of cases of CE, at least in Kazakhstan and Kyrgyzstan have

46 stabalised since about 2003. However, there are now increasing numbers of human cases of alveolar

47 echinoccocsis (AE) being reported in Kyrygzstan (Usubalieva et al. 2013).

49 EPIDEMIOLOGY OF ECHINOCOCCUS GRANULOSUS

50 Human studies.

51 Information regarding the epidemiology of the disease in humans has been obtained from hospital 52 records, official data of reported cases or from a limited number of ultrasound surveillance 
53 community studies. Official data and hospital records indicates that there are many cases in children

54 under 14 years of age - possibly up to one third (Torgerson et al. 2002, 2003a). However, although

55 the mean age of cases from a detailed hospital survey in Kyrgyzstan is very young - approximately

5624 years (Torgerson et al. 2003a) this is not dissimilar to the median age of the population (see data

57 in US Census Bureau, 2012) and the proportion of the Kyrgyz population under 14 years is

58 approximately $35 \%$. Thus, at least in Kyrgyzstan, an important factor is the very young age pyramid

59 of the population. However in the hospital study, the proportion of paediatric cases was somewhat

60 higher after 1997 compared to prior to 1997. This indicates an increasing proportion of children and

61 is consistent with the origins of the epidemic being recent. Other than the young age of cases, there

62 is also an association with unemployment amongst adults - the proportion of adults diagnosed with

$63 \mathrm{CE}$ who were unemployed was double that of the general unemployment rate in the country. A

64 further interesting observation was that those individuals with hepatic cysts tended to be younger

65 than those with pulmonary cysts.

In Kazakhstan the origin of human cases is closely associated with the major sheep rearing areas of the country (Torgerson et al. 2002). In Tajikistan there seem to be a lower proportion of paediatric cases with $7.8 \%$ of cases being less than 14 years of age and $58.7 \%$ being between 18 and 48 years and the average age of hospital treated patients being 36 years of age (Muminov et al. 2004). Most cases (89\%) originated from rural areas. Women were over represented (60.3\%). In addition the incidence varies in different regions. The northern part of the country has the highest incidence being more than twice that of central areas. The southern districts seem to be intermediate in incidence. In Uzbekistan approximately $14.3 \%$ of cases treated between 1999 and 2001 were in children less than 14 years of age, although the proportion of paediatric cases was increasing. Of the adults, $54 \%$ of cases were in women, $46 \%$ men (Nazirov et al. 2002).

Community studies using ultrasound surveillance have also given further clues to the epidemiology of $\mathrm{CE}$ in this region. In Kyrgyzstan a cross-sectional ultrasound survey of 1,486

78 subjects in the Kochkor district revealed 20 with abdominal cysts. This gives an estimated 
79 prevalence of $1.35 \%$. However, because of bias in the population surveyed and potential missing

80 data, the true prevalence of CE might be as high as 3.4\% (Torgerson et al. 2003a). Both these

81 estimates were significantly higher than a survey undertaken in the same area some 10 years

82 previously. Logistic regression revealed that there was an association with infection and the

83 provision of a poor water supply. In a rural community in the east of Kazakhstan 47 cases, either

84 ultrasound positive or recently treated, out of a population of 3,126 were revealed to have CE

85 (Torgerson et al. 2009a). The estimated incidence in this population was 50 cases per 100,000 per

86 year between 2000 and 2005. Large households and /or poor living standards were significantly

87 associated with a diagnosis of CE. Subjects diagnosed with CE also were unable to work for longer

88 periods of time.

89 There is also one study that demonstrated that there is widespread environmental

90 contamination of the surroundings of rural homes with E. granulosus eggs (Shaikenov et al. 2004) .

91 Five of 120 soil samples taken from 30 gardens of rural homesteads were positive for the G1 strain

92 of E. granulosus demonstrating the potential for indirect transmission of E. granulosus to humans

93 from such sources.

95 Livestock studies

96 There have been several studies investigating the increasing prevalence of CE in livestock which

97 has paralleled the increase in human disease incidence. In Uzbekistan the prevalence of

98 echinococcosis in sheep for example has increased from 45\% to $62 \%$ between 1990 and 2002

99 (Aminjanov and Aminjanov, 2004). In Kazakhstan prevalences in sheep have also increased. In the

1001980 s prevalences of approximately 14\% were reported in southern Kazakhstan. By 2000 this had

101 increased to $37 \%$ in the same area (Torgerson et al. 2002). In the Naryn region of central

102 Kyrgyzstan a prevalence of $64 \%$ in sheep was reported in 2006 (Torgerson et al. 2009b). In

103 Tajikistan prevalence varies with region. In high endemic areas in the north, over $50 \%$ of sheep are

104 infected, in central and southern districts sheep generally have approximately a $20 \%$ prevalence and 
areas around the Chinese border just 7\%. Infection varies with age in all regions with young

106 animals having often less than a $10 \%$ prevalence, but the oldest animals having prevalences approaching 80\% (Muminov et al. 2004). There is also some limited data on prevalences in pigs, camels and goats in Uzbekistan and Tadjikistan (see Table 2).

110 districts of Kazakhstan the prevalence in sheep has been reported at between 34 and $48 \%$ and cattle

111 at approximately 7\% (Torgerson et al. 2003b). In sheep there was a mean abundance of 2.54 cysts

112 per sheep from South Kazakhstan and Jambyl Oblasts rising to 4.7 cysts per sheep for other regions.

113 There is increasing abundance and prevalence with age in both populations with sheep acquiring 1.2

114 and 2.0 cysts per year. Cattle had a much lower infection pressure only acquiring 0.15 cysts per

115 year. The reasons for apparent lower infection pressure in cattle compared to sheep is not known,

116 but it could be due to variation in infection pressure through different grazing patterns, variations in

117 parasite genotype between the two species, or the genotype circulating being less infectious to cattle

118 compared to sheep. In the Naryn district of Kyrgyzstan the infection pressure in sheep has been

119 estimated at 1.3 cysts per year - comparable to that seen in neighbouring Kazakhstan (Torgerson et

120 al. 2009b). More detailed analysis was undertaking of the data from Kyrgyzstan with an analysis of

121 the infectious biomass in sheep in terms of the number of infectious protoscoleces. It was

122 demonstrated that $80 \%$ of the infective biomass was in sheep aged 4 years or older, but this 123 represented just $28 \%$ of sheep presented for slaughter.

\section{Studies in definitive hosts}

126 Dogs play an essential role in the transmission cycle of E. granulosus and transmission to man.

127 There have been a number of studies investigating the prevalence and transmission dynamics of $E$.

128 granulosus in dogs across this region. In Tajikistan one study of 120 dogs reported a prevalence of

129 15.2\% (Muminov et al. 2004). In Uzbekistan 531 dogs were investigated using arecoline purgation.

130 Of these 279 were farm dogs of which 56 were shown to be infected $(20.1 \%)$. Of the remaining 240 
131 village dogs, 19 were infected (7.9\%). The differences between the prevalence of the two

132 populations is significant ( $\mathrm{p}<0.001$, Fisher test) (Aminjanov and Aminjanov, 2004). In Kazakhstan

133 there were similar differences between farm dogs and village dogs. A study in southern Kazakhstan

134 indicated that farm dogs had a prevalence of $23 \%$ and an abundance of 631 parasites per dog, whilst

135 village dogs had a much lower prevalence of just 5.8\% with an abundance of 27 parasites per dog

136 (Torgerson et al. 2003c). The differences in prevalence between these groups of dogs was

137 hypothesized to be due to availability of sources of offal. Farm dogs are used largely for 138 shepherding and presumably have greater access to casualty animals. Village dogs, in contrast tend 139 to be kept more as domestic pets. A separate study in Jalanash in eastern Kazakhstan revealed a 140 prevalence of $13 \%$ in a population of 632 dogs with a mean abundance of 812 parasites per dog 141 (Torgerson et al. 2009a). In Kyrgyzstan in Naryn province approximately 19\% of dogs are infected 142 with E. granulosus (Ziadinov et al. 2008). Limited information is available on genotypes of $E$. 143 granulosus and all information is from samples recovered from dogs. Genotypes G1 (E. granulosus 144 senso stricto), G4 (E. equinus) and G6/7 (E. canadensis) have been recovered from dogs in either 145 Kazakhstan and/or Kyrgyzstan (Stefanić et al. 2004; Ziadinov et al. 2008)

146 In Kazakhstan a small study of 41 wolves found 8 infected with E. granulosus (19.5\%) 147 (Abdybekova and Torgerson, 2012). No information is available if the wolves are infected through a 148 wild life cycle or infected through scavenging on sheep.

\section{EPIDEMIOLOGY OF ECHINOCOCCUS MULTILOCULARIS}

\section{Human studies}

152 Human alveolar echinococcosis (AE) has been diagnosed in central Asia in both Kazakhstan and 153 Kyrgyzstan for many years. The first report in Kyrgyzstan was in 1948 from archival material 154 dating from as early as 1935 . Further cases were reported in the Soviet Literature between 1960 and 1551988 (reviewed by (Abdyjaparov and Kuutubaev, 2004). In Kazakhstan, 19 of 1435 cases of 156 echinococcosis reported in Almaty hospitals between 1989 and 2003 were possible AE cases, whilst 
1574 cases of 205 cases of echinococcosis treated at the Institute of Experimental Surgery in Almaty

158 were confirmed as AE (Shaikenov and Torgerson, 2004).

Recently strong evidence that human $\mathrm{AE}$ is an emergent diseases has been reported, at least

160 in Kyrgyzstan. Up until 2003, only sporadic cases were reported, typified by the summaries given

161 above. But since then, from just 0-3 cases per year, the numbers of AE cases now being reported is

162 over 60 cases per year (Usubalieva et al. 2013) (Figure 1). The cases have all been confirmed

163 histologically and the evidence appears to appoint to a newly emerging epidemic rather than

164 improved diagnosis. Naryn district has by far the highest incidence with over 7 cases per 100,000

165 per year for 2010-2011. However, cases are being seen in every district of Kyrgyzstan.

166 Approximately 64\% cases are in females and the mean age of diagnosis is much younger than in

167 Europe at just 33.4 years of age compared to 54 years in Switzerland for example. It is likely that

168 the relative youth of cases of human $\mathrm{AE}$ is a reflection of the population structure of the country as

169 the median age of the Kyrgyz population is just 24 years.

Although it is likely that E. multilocularis is endemic in the other three republics of central

171 Asia, at the time of writing it was not possible able to access any data or reports other than those

172 described for Kazakhstan and Kyrgyzstan.

\section{Intermediate hosts}

175 This parasite has long been known to be endemic in central Asia with extensive studies being

176 undertaken by Shaikenov in intermediate hosts both before and after the dissolution of the Soviet

177 Union. Much of the data from these studies is reviewed in Shaikenov (2004a, 2004b, 2006). From

178 data collected over several decades it was shown that E. multilocularis has a very patchy

179 distribution in Kazakhstan. In arid regions infection of small mammals are usually only found in

180 areas where there is moisture or higher levels of humidity such as in desert oases or river and stream

181 valleys. In the mountains in the south of Kazakhstan or the forest steppe in the north, infections of

182 small mammal hosts appear to be more extensive. In Kyrgyzstan there have been studies on rodents 
183 of mountainous pastures (Abdyjaparov and Kuttubaev, 2004). Prevalences of up to 4\% were seen in

184 species such as the grey marmot (Marmota baibacina) and Gopher (Citellus relictus), with a

185 number of other species also being infected.

Definitive hosts

188 A recent study of red foxes (Vulpes vulpes) in Naryn region indicated a high prevalence of 189 approximately 65\% (Ziadinov et al. 2010). Infection of domestic dogs has been recorded in the 190 mountainous region of south east Kazakhstan. This was first detected in a study in 2002. Of 131 191 dogs 6 were shown to be infected with E. multilocularis (Stefanić et al. 2004). One of these dogs 192 was infected with both E. granulosus and E. multilocularis. This is one of the first reports of a 193 naturally occurring dual infection with both parasites in a dog. Subsequent studies in the same 194 district between 2003 and 2005 indicated a prevalence of 5\% (29 of 632 dogs) using arecoline 195 purgation (Torgerson et al. 2009a). However because of the poor sensitivity of arecoline purgation 196 the true prevalence is likely to be higher. In Naryn province, Kyrgyzstan, a prevalence of $18 \%$ was estimated in dogs using a combination of arecoline purgation and PCR methods and estimating the

198 true prevalence using latent class methods (Ziadinov et al. 2008) (Table 2). Dogs that were not tied 199 and hence had greater opportunities to roam, hunt and scavenge had substantial higher prevalences $200(26 \%)$ than dogs that were tied up for most of the time (11\%).

Hypothesis for human AE emergence in Kyrgyzstan

203 The emergence of AE in Kyrgyzstan could be linked to the socio-economic changes that occurred 204 following the dissolution of the Soviet Union. There was certainly increased transmission of CE to 205 humans as outlined above. Thus it can be hypothesised that with increased numbers of dogs and 206 widespread rural poverty E. multilocularis colonised dogs which were forced to hunt or forage for 207 food, as suggested by the higher relative risk of infection in free roaming dogs (Ziadinov et al. 208 2008). So it is possible that following colonisation of dogs, the increase in AE is a result of 
209 increased dog-human contact. Such increased dog-human contact is proven by the increasing

210 incidence of human CE since dogs are the obligatory definitive host of E. granulosus. In addition

211 the increase in the numbers of AE cases appeared approximately 15 years after the dissolution of

212 the Soviet Union, which is the same as the estimated latent period of AE in humans. Further

213 investigations are being undertaken and unpublished evidence suggests that in some communities

214 the ultrasound prevalence of AE may be as high as 7\%.

216 CONCLUSIONS

217 It is clear that there has been a substantive increase in the numbers of cases of human 218 echinococcosis being diagnosed since the collapse of the Soviet Union. Likewise there appears to 219 be increases in the prevalences of E. granulosus in livestock and in dogs. Both these phenomena are 220 likely caused by the reorganisation of livestock farming with the privatisation of large collectivised 221 livestock units. This also led to the closure of large meat processing units and less supervision of 222 meat processing by the veterinary public health services. Dog populations increased and there was a 223 requirement of larger numbers of dogs for shepherding the increased numbers of small livestock 224 units. This provided the opportunity for increased transmission of E. granulosus (Shaikenov et al. 225 2003). Increases in free roaming dog populations scavenging for food may have provided an 226 opportunity for E. multilocularis to colonise dogs and the close contact of dogs with humans has 227 allowed transmission of E. multilocularis from dogs to humans. These may be the reasons that there 228 are now increasing numbers of human AE cases being reported in Kyrgyzstan (Usubalieva et al. 229 2013).

\section{ACKNOWLEDGEMENTS}

232 Much of the works reviewed in this article was supported by INTAS, Swiss National Funds 233 (SCOPES programme), the NIH and the Welcome Trust. 
REFERENCES

Abdybekova, A. M. and Torgerson, P. R. (2012). Frequency distributions of helminths of wolves in Kazakhstan. Veterinary Parasitology 184, 348-351. doi: 10.1016/j.vetpar.2011.09.004

Abdyjaparov, T. A. and Kuttubaev, O. T. (2004). Alveolar echinococcosis in rodents of mountainous pastures of Kyrgystan. In Echinococcosis in Central Asia: Problems and Solutions. (ed. Torgerson, P. and Shaikenov, B), pp 253-262. Dauir Publishing House, Almaty, Kazakhstan.

Aminjanov, M. and Aminjanov, S. (2004). Echinococcosis and research in Uzbekistan. In Echinococcosis in Central Asia: Problems and Solutions. (ed. Torgerson, P. and Shaikenov, B), pp. 13-19. Dauir Publishing House, Almaty, Kazakhstan.

Becker, C. M. and Hemley, D. D. (1998). Demographic change in the former Soviet Union during the transition period. World Development 26, 1957-1975.

Becker, C. M. and Urzhumova, D. S. (2005). Mortality recovery and stabilization in Kazakhstan, 1995-2001. Economics \& Human Biology 3, 97-122.

Kuttubaev, O. T., Kasimbekov, B. K., Omorov, R. A. and Karaeva, R. R. (2004). Echinococcosis in the Kyrgyz Republic. In Echinococcosis in Central Asia: Problems and Solutions.(ed. Torgerson, P. and Shaikenov, B), pp. 31-42. Dauir Publishing House, Almaty, Kazakhstan.

Muminov, A. M., Mahmadov, F. I. and Shodmonov, I. S. (2004). Echinococcosis of people and animals of Tadjikistan. In Echinococcosis in Central Asia: Problems and Solutions. (ed. Torgerson, P. and Shaikenov, B), pp. 20-24. Dauir Publishing House, Almaty, Kazakhstan.

Nazirov, F. G., Ilkhamov, I. L. and Ambekov, N.C. (2002). Echinococcosis in Uzbekistan: types of problems and methods to improve treatment. Medical Journal of Uzbekistan 2/3, 2-5.

Shaikenov, B. (2004a). Ecology of Echinococcus multilocularis. Features of natural endemic foci in the southern deserts of Kazakhstan. In Echinococcosis in Central Asia: Problems and Solutions (ed. Torgerson, P. and Shaikenov, B), pp237-245. Dauir Publishing House, 
Almaty, Kazakhstan.

Shaikenov, B. S. (2004b). Seasonal dynamics of the transmission of Echinococcus multilocularis. In Echinococcosis in Central Asia: Problems and Solutions (ed. Torgerson, P. and Shaikenov, B), pp283-288 Dauir Publishing House, Almaty, Kazakhstan.

Shaikenov, B. S. (2006). Distribution and ecology of Echinococcus multilocularis in Central Asia. Parasitology International 55, S213-219. doi:10.1016/j.parint.2005.11.033.

Shaikenov, B. S., Rysmukhambetova, A. T., Massenov, B., Deplazes, P., Mathis, A. and Torgerson, P. R. (2004). Short report: the use of a polymerase chain reaction to detect Echinococcus granulosus (G1 strain) eggs in soil samples. American Journal of Tropical Medicine and Hygiene 71, 441-443.

Shaikenov, B. S., Torgerson, P. R., Usenbayev, A. E., Baitursynov, K. K., Rysmukhambetova, A. T., Abdybekova, A. M. and Karamendin, K. O. (2003). The changing epidemiology of echinococcosis in Kazakhstan due to transformation of farming practices. Acta Tropica 85, 287-293. doi: 10.1016/S0001-706X(02)00236-X.

Shaikenov, B. and Torgerson, P. R. (2004). Changes in the epidemiology of echinococcosis in Kazakhstan. In Echinococcosis in Central Asia: Problems and Solutions (ed. Torgerson, P. and Shaikenov, B), pp 3-12, Dauir Publishing House, Almaty, Kazakhstan.

Stefanić, S., Shaikenov, B.S., Deplazes, P., Dinkel, A., Torgerson, P.R. and Mathis, A. (2004). Polymerase chain reaction for detection of patent infections of Echinococcus granulosus (“sheep strain”) in naturally infected dogs. Parasitology Research 92, 347-351.

Stillman, S. (2006). Health and nutrition in Eastern Europe and the former Soviet Union during the decade of transition: a review of the literature. Economics and Human Biology 4, 104-146. doi:10.1016/j.ehb.2005.04.005.

Torgerson, P.R., Shaikenov, B.S., Baitursinov, K.K. and Abdybekova, A.M. (2002). The emerging epidemic of echinococcosis in Kazakhstan. Transactions of the Royal Society of Tropical Medicine and Hygiene 96, 124-128. doi: 10.1016/S0035-9203(02)90276-2. 
Torgerson, P.R., Karaeva, R.R., Corkeri, N., Abdyjaparov, T.A., Kuttubaev, O.T. and Shaikenov, B.S. (2003a). Human cystic echinococcosis in Kyrgystan: an epidemiological study. Acta Tropica 85, 51-61. doi: 10.1016/S0001-706X(02)00257-7.

Torgerson, P.R., Burtisurnov, K.K., Shaikenov, B.S., Rysmukhambetova, A.T., Abdybekova, A.M. and Ussenbayev, A.E. (2003b). Modelling the transmission dynamics of Echinococcus granulosus in sheep and cattle in Kazakhstan. Veterinary Parasitology 114, 143-153. doi: 10.1016/S0304-4017(03)00136-5.

Torgerson, P.R., Shaikenov, B.S., Rysmukhambetova, A.T., Ussenbayev, A.E., Abdybekova, A.M. and Burtisurnov, K.K. (2003c). Modelling the transmission dynamics of Echinococcus granulosus in dogs in rural Kazakhstan. Parasitology 126, 417-424. doi: 10.1017/S0031182003002932.

Torgerson, P.R., Oguljahan, B., Muminov, A.E., Karaeva, R.R., Kuttubaev, O.T., Aminjanov, M. and Shaikenov, B. (2006). Present situation of cystic echinococcosis in Central Asia. Parasitology International 55, S207-212. doi: 10.1016/j.parint.2005.11.032.

Torgerson, P.R., Rosenheim, K., Tanner, I., Ziadinov, I., Grimm, F., Brunner, M., Shaiken, S., Shaikenov, B., Rysmukhambetova, A. and Deplazes, P. (2009a). Echinococcosis, toxocarosis and toxoplasmosis screening in a rural community in eastern Kazakhstan. Tropical Medicine and International Health 14, 341-348. doi: 10.1111/j.13653156.2009.02229.x.

Torgerson, P.R., Ziadinov, I., Aknazarov, D., Nurgaziev, R. and Deplazes, P. (2009b). Modelling the age variation of larval protoscoleces of Echinococcus granulosus in sheep. International Journal for Parasitology 39, 1031-1035. doi: 10.1016/j.ijpara.2009.01.004.

US Census Bureau, D.I.S. (2012). International Programs, International Data Base http://www.census.gov/population/international/data/idb/region.php (accessed 12.20.12).

Usubalieva, J., Minbaeva, G., Ziadinov, I., Deplazes, P. and Torgerson, P. R. (2013). Emergence of Human Alveolar Echinococcosis in Kyrgyzstan. Emerging Infectious Diseases 19, 1095- 
1097 doi: 10.3201/eid1907.121405.

Ziadinov, I., Mathis, A., Trachsel, D., Rysmukhambetova, A., Abdyjaparov, T. A., Kuttubaev, O. T., Deplazes, P. and Torgerson, P. R. (2008). Canine echinococcosis in Kyrgyzstan: Using prevalence data adjusted for measurement error to develop transmission dynamics models. International Journal for Parasitology 38, 1179-1190. doi: 10.1016/j.ijpara.2008.01.009.

Ziadinov, I., Deplazes, P., Mathis, A., Mutunova, B., Abdykerimov, K., Nurgaziev, R. and Torgerson, P. R. (2010). Frequency distribution of Echinococcus multilocularis and other helminths of foxes in Kyrgyzstan. Veterinary Parasitology 171, 286-292.doi: 10.1016/j.vetpar.2010.04.006.

243 Figure 1. Changes in the numbers of reported cases of human AE in Kyrgyzstan, 1996-2011 (data 244 from Usubalieva et al. 2013). 
245 Table 1. Changes in the annual reported incidence of echinococcosis in central Asia following the 246 collapse of the Soviet Union

247

\begin{tabular}{|c|c|c|c|}
\hline \multirow[b]{2}{*}{ Kazakhstan } & \multicolumn{2}{|c|}{ Changes in Annual Incidence (year) } & \multirow{2}{*}{$\begin{array}{l}\text { Source } \\
\text { (Shaikenov and Torgerson, 2004; } \\
\text { Torgerson et al. 2002) }\end{array}$} \\
\hline & $\begin{array}{l}1.4 \text { per } 100,000 \\
(1991)\end{array}$ & $\begin{array}{l}6.5 \text { per } 100,000 \\
(2003)\end{array}$ & \\
\hline Kyrgyzstan & $\begin{array}{l}5 \text { per } 100,000 \\
(1991)\end{array}$ & $\begin{array}{l}20 \text { per } 100,000 \\
(2002)\end{array}$ & $\begin{array}{l}\text { (Kuttubaev et al. 2004; Torgerson et } \\
\text { al. 2003b) }\end{array}$ \\
\hline Tadjikistan & $\begin{array}{l}6.8 \text { per } 100,000 \\
(1992)\end{array}$ & $\begin{array}{l}28 \text { per } 100,000 \\
(2002)\end{array}$ & (Muminov et al. 2004) \\
\hline Turkmenistan & $\begin{array}{l}\text { c } 6 \text { per } 100,000 \\
(1978)\end{array}$ & $\begin{array}{l}17 \text { per } 100,000 \\
(2000)\end{array}$ & (Torgerson et al. 2006) \\
\hline Uzbekistan & $\begin{array}{l}2 \text { per } 100,000 \\
\text { (1988, official } \\
\text { figures) }\end{array}$ & $\begin{array}{l}\text { c } 5 \text { per } 100,000 \\
\text { ( } 2000-2001, \\
\text { official figure) } \\
\text { c } 17 \text { per } 100,000 \\
\text { (case finding } \\
\text { studies } 2000- \\
2001 \text { ) }\end{array}$ & $\begin{array}{l}\text { (Aminjanov and Aminjanov, 2004; } \\
\text { Nazirov et al. 2002) }\end{array}$ \\
\hline
\end{tabular}


250 Table 2. Summary of livestock prevalences and transmission dynamics reported from central Asia 251

\begin{tabular}{|c|c|c|c|c|}
\hline Region & Date of study & Host species & Findings & Reference \\
\hline $\begin{array}{l}\text { South } \\
\text { Kazakhstan }\end{array}$ & $2001-2002$ & Sheep & $\begin{array}{l}732(34 \%) \text { of } 2,152 \\
\text { infected. Infection } \\
\text { pressure } 23 \% \text { per year }\end{array}$ & (Torgerson et al. 2003a) \\
\hline Kazakhstan & 2001-2002 & Sheep & $\begin{array}{l}169(48 \%) \text { of } 353 \\
\text { infected. Infection } \\
\text { pressure } 29 \% \text { per year. }\end{array}$ & (Torgerson et al. 2003a) \\
\hline $\begin{array}{l}\text { South } \\
\text { Kazakhstan }\end{array}$ & 2001-2002 & Cattle & $\begin{array}{l}31(7.2 \%) \text { of } 431 \\
\text { infected. Infection } \\
\text { pressure } 2.7 \% \text { per year }\end{array}$ & (Torgerson et al. 2003a) \\
\hline $\begin{array}{l}\text { Naryn, } \\
\text { Kyrgyzstan }\end{array}$ & 2006 & Sheep & $\begin{array}{l}694(64 \%) \text { of } 1,081 \\
\text { infected }\end{array}$ & (Torgerson et al. 2009b) \\
\hline $\begin{array}{l}\text { Central } \\
\text { Tajikistan }\end{array}$ & Not stated & $\begin{array}{l}\text { Sheep and } \\
\text { goats }\end{array}$ & $\begin{array}{l}401(11.8 \%) \text { of } 3400 \\
\text { infected }\end{array}$ & (Muminov et al. 2004) \\
\hline $\begin{array}{l}\text { Southern } \\
\text { Tajikistan }\end{array}$ & Not stated & $\begin{array}{l}\text { Sheep and } \\
\text { goats }\end{array}$ & $\begin{array}{l}* 36.2 \% \text { in adults, } 7.8 \% \\
\text { in young animals, } 25.2 \% \\
\text { in goats }\end{array}$ & (Muminov et al. 2004) \\
\hline $\begin{array}{l}\text { Central } \\
\text { Tajikistan }\end{array}$ & Not stated & Cattle & $* 2.5 \%$ & (Muminov et al. 2004) \\
\hline $\begin{array}{l}\text { South-west and } \\
\text { east Tajikistan }\end{array}$ & Not stated & Cattle & $* 7.9 \%$ & (Muminov et al. 2004) \\
\hline Tajikistan & Not stated & Pigs & $\begin{array}{l}33(2.1 \%) \text { of } 1,601 \\
\text { animals }\end{array}$ & (Muminov et al. 2004) \\
\hline Uzbekistan & $1990-2002$ & Sheep & $\begin{array}{l}* \text { Increasing from } 45 \% \text { to } \\
62 \%\end{array}$ & $\begin{array}{l}\text { (Aminjanov and } \\
\text { Aminjanov, 2004) }\end{array}$ \\
\hline Uzbekistan & $1990-2002$ & Goats & $\begin{array}{l}* \text { Increasing from } 8 \% \text { to } \\
11.1 \%\end{array}$ & $\begin{array}{l}\text { (Aminjanov and } \\
\text { Aminjanov, 2004) }\end{array}$ \\
\hline Uzbekistan & $1990-2002$ & Cattle & $\begin{array}{l}* \text { Increasing from } 24 \% \text { to } \\
46 \%\end{array}$ & $\begin{array}{l}\text { (Aminjanov and } \\
\text { Aminjanov, 2004) }\end{array}$ \\
\hline Uzbekistan & $1990-2002$ & Camels & $\begin{array}{l}* \text { Increasing from } 25 \% \text { to } \\
35 \%\end{array}$ & $\begin{array}{l}\text { (Aminjanov and } \\
\text { Aminjanov, 2004) }\end{array}$ \\
\hline
\end{tabular}


255 Table3. Echinococcus in definitive hosts in central Asia

\begin{tabular}{|c|c|c|c|c|c|}
\hline Region & Date of study & $\begin{array}{l}\text { Host } \\
\text { species }\end{array}$ & $\begin{array}{l}\text { Diagnostic } \\
\text { method }\end{array}$ & Findings & Reference \\
\hline $\begin{array}{l}\text { Villages, south } \\
\text { Kazakhstan }\end{array}$ & 1999-2001 & Dog & $\begin{array}{l}\text { Arecoline } \\
\text { purgation }\end{array}$ & $\begin{array}{l}90(5.8 \%) \text { of } 1,552 \text { infected } \\
\text { with } E . \text { granulosus. Mean } \\
\text { abundance } 27 \text { parasites per } \\
\text { dog }\end{array}$ & $\begin{array}{l}\text { (Torgerson et al. } \\
2003 \mathrm{c} \text { ) }\end{array}$ \\
\hline $\begin{array}{l}\text { Farms, South } \\
\text { Kazakhstan }\end{array}$ & 1999-2001 & Dog & $\begin{array}{l}\text { Arecoline } \\
\text { purgation }\end{array}$ & $\begin{array}{l}145(23 \%) \text { if } 630 \text { farms dogs } \\
\text { infected with E. granulosus. } \\
\text { Mean abundance } 631 \\
\text { parasites per dog }\end{array}$ & $\begin{array}{l}\text { (Torgerson et al. } \\
2003 \mathrm{c} \text { ) }\end{array}$ \\
\hline $\begin{array}{l}\text { Jalanash, south } \\
\text { east } \\
\text { Kazakhstan }\end{array}$ & 2002 & Dog & $\begin{array}{l}\text { PCR and } \\
\text { arecoline } \\
\text { purgation }\end{array}$ & $\begin{array}{l}8 \text { of } 131(26 \%) \text { dogs infected } \\
\text { with } E \text {. granulosus, } 6 \text { of } 131 \\
(4.6 \%) \text { infected with } E . \\
\text { multilocularis. One dog was } \\
\text { infected with both parasites }\end{array}$ & $\begin{array}{l}\text { (Stefanić et al. } \\
\text { 2004) }\end{array}$ \\
\hline $\begin{array}{l}\text { Jalanash, South } \\
\text { east } \\
\text { Kazakhstan }\end{array}$ & 2003-2005 & Dog & $\begin{array}{l}\text { Arecoline } \\
\text { Purgation }\end{array}$ & $\begin{array}{l}85(13 \%) \text { of } 632 \text { dogs } \\
\text { infected with } \text { E. granulosus. } \\
\text { Mean abundance } 812 \\
\text { parasites. } 29(5 \%) \text { of } 632 \\
\text { dogs infected with } E . \\
\text { multilocularis. Mean } \\
\text { abundance } 72 \text { parasites per } \\
\text { dog }\end{array}$ & $\begin{array}{l}\text { (Torgerson et al. } \\
\text { 2009a) }\end{array}$ \\
\hline $\begin{array}{l}\text { South } \\
\text { Kazakhstan }\end{array}$ & 2001-2008 & Wolf & Necropsy & $\begin{array}{l}8 \text { of } 41(20 \%) \text { wolves } \\
\text { infected with E. granulosus. } \\
\text { Mean abundance of } 1275 \\
\text { parasites per wolf }\end{array}$ & $\begin{array}{l}\text { (Abdybekova and } \\
\text { Torgerson, 2012) }\end{array}$ \\
\hline $\begin{array}{l}\text { Naryn District, } \\
\text { Kyrgyzstan }\end{array}$ & 2005 & Dog & $\begin{array}{l}\text { Arecoline } \\
\text { purgation, } \\
\text { PCR of } \\
\text { faeces }\end{array}$ & $\begin{array}{l}\text { True prevalence in dogs of } E \text {. } \\
\text { granulosus } 19 \% \text { and } E \\
\text { multilocularis } 18 \% \text { in } 466 \\
\text { dogs }\end{array}$ & $\begin{array}{l}\text { (Ziadinov et al. } \\
\text { 2008) }\end{array}$ \\
\hline Kyrgyzstan & 1991-2001 & Dog & Necropsy & $\begin{array}{l}\text { Increase in prevalence from } \\
4.8 \% \text { to } 11.2 \% \text { of } E \text {. } \\
\text { granulosus }\end{array}$ & $\begin{array}{l}\text { (Kuttubaev et al. } \\
\text { 2004) }\end{array}$ \\
\hline $\begin{array}{l}\text { Naryn District, } \\
\text { Kyrgyzstan }\end{array}$ & 2006-2007 & Fox & Necropsy & $\begin{array}{l}96(64 \%) \text { of } 151 \text { foxes } \\
\text { infected with } E \text {. } \\
\text { multilocularis. Mean } \\
\text { abundance of } 8,669 \text { parasites } \\
\text { per fox. }\end{array}$ & $\begin{array}{l}\text { (Ziadinov et al. } \\
\text { 2010) }\end{array}$ \\
\hline Tajikistan & Not stated & Dog & Necropsy & $\begin{array}{l}18(15 \%) \text { of } 120 \text { dogs } \\
\text { infected with E. granulosus }\end{array}$ & $\begin{array}{l}\text { (Muminov et al. } \\
\text { 2004) }\end{array}$ \\
\hline Uzbekistan & c 2003 & Dog & $\begin{array}{l}\text { Arecoline } \\
\text { purgation }\end{array}$ & $\begin{array}{l}56(20 \%) \text { of } 279 \text { farm dogs } \\
\text { infected with } E \text {. granulosus }\end{array}$ & $\begin{array}{l}\text { (Aminjanov and } \\
\text { Aminjanov, 2004) }\end{array}$ \\
\hline Uzbekistan & C 2002 & Dog & $\begin{array}{l}\text { Arecoline } \\
\text { purgation }\end{array}$ & $\begin{array}{l}19(7.9 \%) \text { of } 240 \text { village dogs } \\
\text { infected with } E \text {. granulosus }\end{array}$ & $\begin{array}{l}\text { (Aminjanov and } \\
\text { Aminjanov, 2004) }\end{array}$ \\
\hline
\end{tabular}




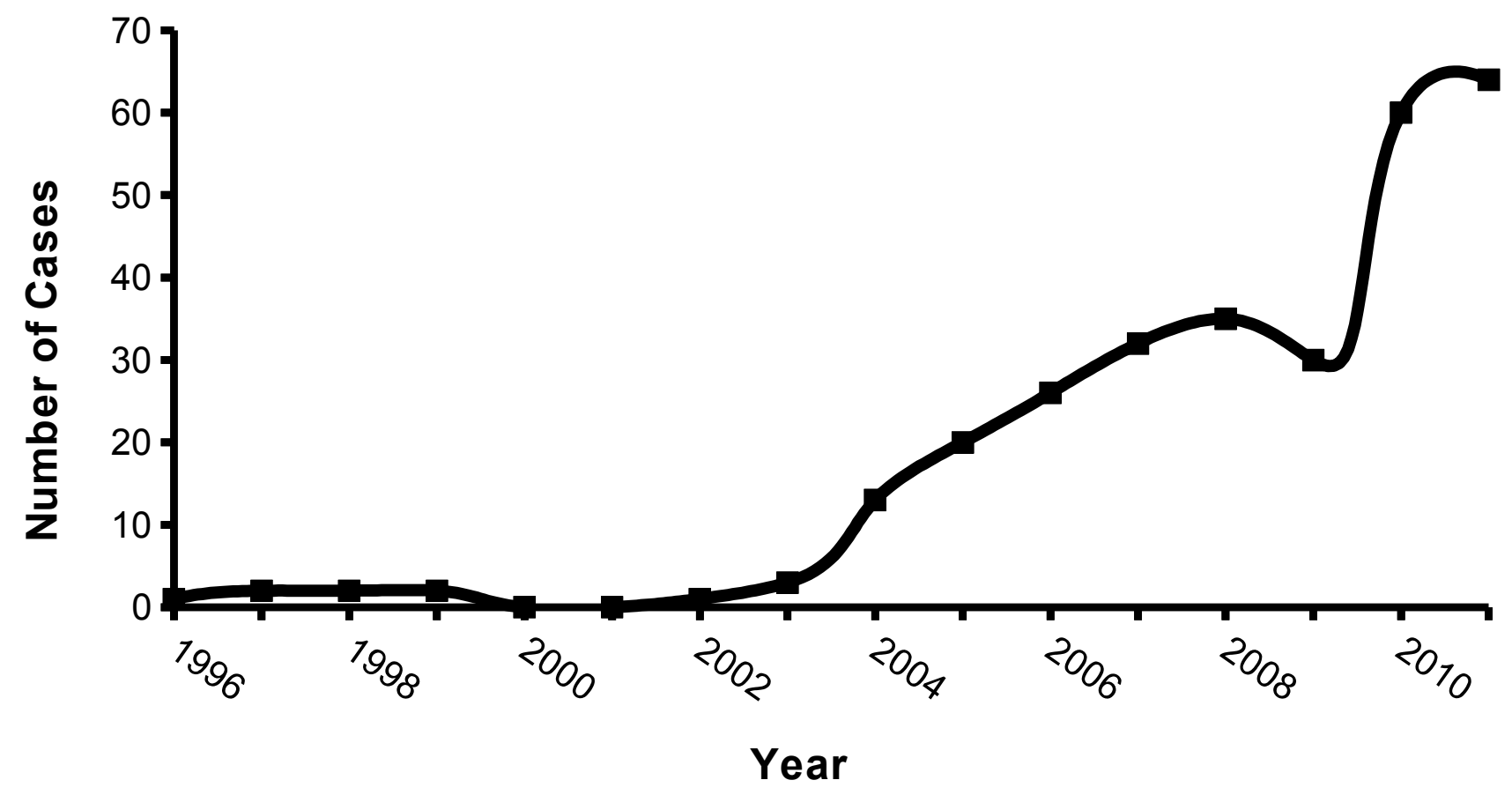

